\title{
新築戸建住宅における様式・材 THE PROCESS OF SPREADING OF THE 料の普及プロセスに関する研究 STYLES AND MATERIALS CONCERNING NEWLY BUILT DETACHED HOUSING IN JAPAN
}

谷口尚弘—*1 大垣直明 $-* 2$

キーワード :

住宅生産・供給，住宅様式・材料，地域性，普及プロセス

Keywords :

housing, newly built detached houses, styles and materials, regional differences, process of spreading

\section{Naohiro TANIGUCHI $-* 1$}

\section{Naoaki OHGAKI $-* 2$}

The purpose of this study is to clear the mechanism on process of spreading of the styles and materials concerning newly built detached houses in Japan. As a result, we cleared the followings,

1) The speed of spreading is different among styles and materials.

2) The modern styles and materials decline by the predominance of the other modern styles and materials.

3) The traditional styles and materials are declining but except for symbolic styles.

4) The area of spreading of the styles and materials which is influenced by the climate doesn't change.

\section{1. はじめに}

近年, 全国各地の戸建住宅供給は画一化の方向に進行している。 このことは, 新しい住宅様式・材料の採用・普及を進め, 地域固有 性の崩壊, すなわち生活スタイルや地域景観の変化, 新たな供給シ ステムの進展による大工組織・地域経済の衰退, 流行的現象といっ た問題につながっている"。筆者は，近年の住宅の画一化現象に着 目し，それを引き起こしている住宅様式・材料の普及構造（地理的 関倸からみた普及構造）を明らかにし，地域条件を尊重した新しい 住宅生産・供給のあり方, 地域性を考慮した住宅のあり方を再構筑 しなければならないと位置づけている。

住宅様式・材料の普及過程は，新しい「もの」が決定・採用され 普及していく過程であり，逆にいえば古い「もの」が浸食されてい く過程でもある。その普及過程で起こりうる現象は多様であり，た とえば一定程度普及して衰退していく場合, 緒につきすぐ廃れてい く場合などが存在していると考えられる（図－1）。つまり普还化 に至るまではなんらかの法則性が存在し，その法則性は住宅様式・ 材料によって異なっていると考えられる。また「普及」とは，住宅 様式・材料の地域性が介在していた地域枠を越えて一般的に広がる 過程であり，「普及」の構造を捉える場合，巽も述べているように 2)，空間と時間の両方で㧿えなければならないと考えている。

既往研究において圏域（空間）形成を主眼に提えた結果，近代的 様式・材料の圈域形成には単独の要囚で圈域が形成されている都市 型圈域, 北方型圈域, 南方型圈域と, 異なる 2 つ要因で形成され る北方型圈域と生産基盤型圈域が存在を明らかにしている $\left.{ }^{3 !}\right)^{4}$, このことは近年の生活慣習の近代化や住宅生産のネットワーク化に も関わらず, 住宅様式・材料の「普及」の現象はその地域の条件と
結びつき，採用・普及していることを示している。

そこで本研究は，それらを踏まえ各住宅様式・材料が時間経過に よって，どのように採用・普及（衰退）しているのか，普及圈域が どのように変化しているのか, 空間と時間の両方から住宅様式・材 料の「普及」について明らかにすることが目的である。

本研究に用いたデー夕は「建筑・住宅主要デー夕調査報告」であ る”。このデータは年度によって調査対象の住宅様式・材料は異な っているが，それぞれ数年おきに調査されており，住宅様式・材料 の普及ブロセスを扑えられる貴重なデータである。

2. 住宅样式・材料の採用状況の変化

まず採用率平均（全国的採用状況）をもとに各住宅様式・材料別 の採用状況の变化についてみる（図一-2）。

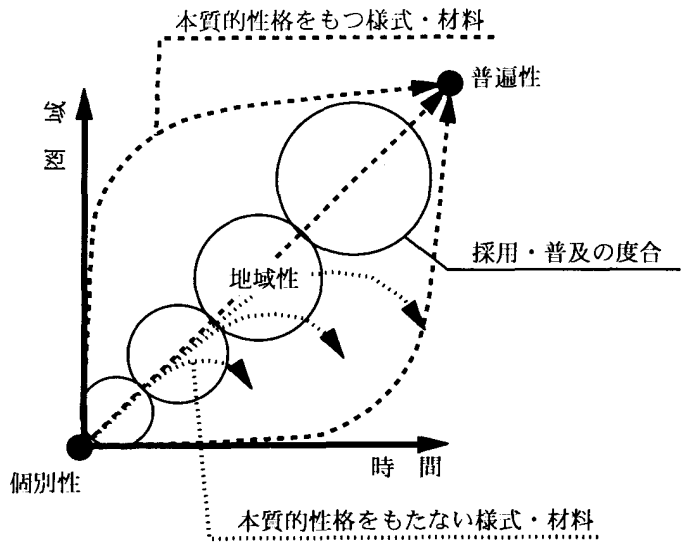

図一 1 普及構造の概念図

\footnotetext{
${ }^{* 1}$ 北海道工業大学工学部建築工学科 非常勤講師・博士(工学)

( (006-8585 札帽市手稲区前田7条15丁目4-1)

$* 2$ 北海道工業大学工学部建築工学科 教授・工博
}

*1 Lecturer (Part-time), Dept. of Architecture, Hokkaido Institute of Technology, Dr. Eng.

*2 Prof., Dept. of Architecture, Hokkaido Institute of Technology, Dr. Eng. 


\section{1 近代的様式・材料の採用状況の変化}

近代的様式・材料のほとんどは年度が経過するにしたがって採用 ・普及の比率が高くなっている。その中で洋間の居間および壁紙 （居間の壁仕上げ材）は昭和162年度でも $74.5 \% ， 87.7 \%$ と高く, 以 前から採用・普及の高原状態を維持し, 普遍的様式・材料と位置づ けることができる。これに対し両ボード類および方形は, 昭和 62 年 度でも低く, 年度が経過しても增加していなく，これらは今後も採 用・普及していかないものと考えられる。システムキッチン, ユニ ットバス, 屋根の断熱材の厚さ，人造大理石は急速に採用・普及し ているのに対し, 開き戸, 悹サッシの多重化, 壁の断熱材の厚さ, サイディング，彩色石綿板，寄棟，ブラスチック，壁紙（居間の壁 仕上げ材）の採用・普及速度は早くない。また近代的様式・材料で あるにも関わらず採用状況は減少しているのは, モルタル・コンク リートおよびステンレスであり，モルタル・コンクリートはサイデ ィング，ステンレスはブラスチックといった新しい住宅様式・材料 が開発・普及され, 後者のほうが優位性（施工上, 気密性など ${ }^{4 !}$ ) が高いことを示している。また，年度が経過してもほぼ変化がない のは金属板，スレート瓦，陸屋根，無落雪屋根であり，これらはあ る一定の地域のみで採用・普及していること, とりわけ金属板は北 方地域の中の日本海側のみで, 無落雪屋根は北方地域のなかで北海 道および青森のみで採用・普及している結果である ${ }^{3 !} 。$

\section{2 伝統的様式・材料の採用状況の变化}

伝統的様式・材料は近代的様式・材料と逆の傾向を示し, 年度が 経過するにしたがって採用状況の比率が低くなっている。その中で 雨戸をみると， $67.1 \%$ （昭62） $\rightarrow 67.6 \%$ (昭63） $\rightarrow 65.0 \%$ (平 3 ） $\rightarrow 66.8 \%$ (平 5 ) $\rightarrow 65.7 \%$ (平 7 ) とほとんど変化がなく, 特異な 採用状況を示す伝統的様式である。このことは採用状洗が高い地域 と低い地域がほぼ变化なく推移していることを示している（第 3 章 参照）。さらに仏壇置き場および床の間は減少はしているもののい

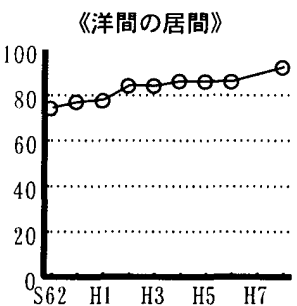

《床の間》

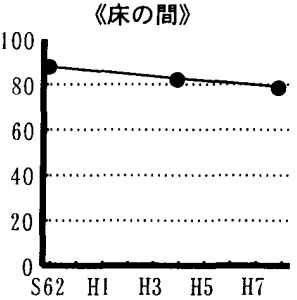

《外壁の材料》

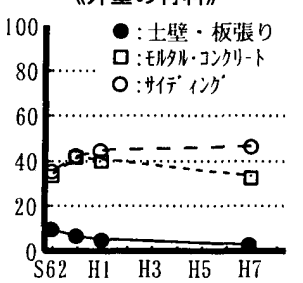

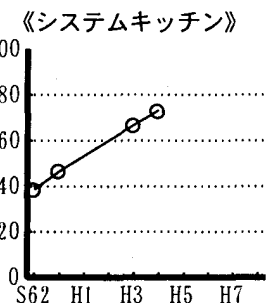

《続き間》

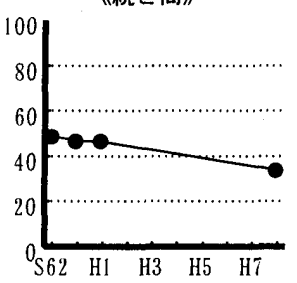

《屋根の材料》

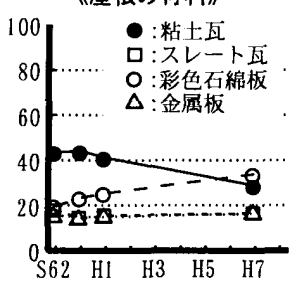

《開き戸（玄閣戸）》

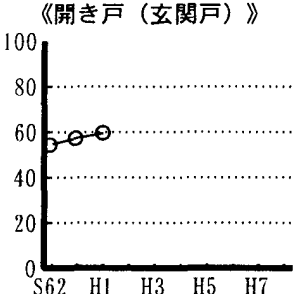

《和室数》

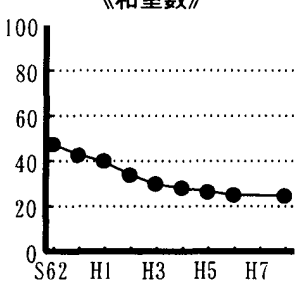

《屋根の形態》



まだに高い採用状況を示しており，精视性に関わる住宅様式は减少 の速度が遐い。採用状況は下がるが, 減少率が小さいのは切妻およ びホーローであり，切妻においては居住者の屋根形態に対するデザ インの固執と地域における伝統性の強さによると考えられる。これ に対し減少率が大きいのは続き間, 和室数, 粘土瓦, 湿式（和室の 壁仕上げ材）であり，粘土瓦は彩色石綿板，湿式は壁紙に置き換え らた結果であろう。また続き間および利室数は, 都市化の進行によ って生活スタイルの急激な変化が減少を早めている ${ }^{6 !}$ 。

これらのことより総じて近代的様式・材料は増加傾向にあり，伝 統的様式・材料は減少すなわち衰退傾向にあるが, 減少の傾向は住 宅様式・材料によって異なっており, 採用・普及の速度にも住宅様 式・材料差が生じている。

\section{3. 圈域形成のプロセスの変化と背景}

次に, 時間的断面による圈域の形成構造，すなわちどのように圈 域が形成され变化しているのか, さらにその背景についてみる。

近代的様式・材料の一般的な普及圈域の形成のプロセスは, 普及 の緒となる地域が存在し, そこから地理的に連続して周辺の都道府 県に普及し，1つの圈域が形成され，その後時間の経過とともに複 数の圈域が形成される。さらに, 普及が進行すると山と他の山との 間で採用状況に差がなくなり，やがて高原状態すなわち圈域がなく なり普掘性となる ${ }^{6)}$

システムキッチンをみると（図－3）, 昭和62年度では北海道, 奈良, 熊本を起点とした圈域が存在し, また東京は小さな山の頂点 として機能しており, 平成 3 年度では東京を起点（普及の極地）と した圈域が形成されている。地方中核都市を含む北海道および福岡 （昭和62年度では熊本であるが，福岡も高い採用状況である）でも 奈良と同様に，平成 3 年度でも採用を伸ばしている。また平成 3 年 度では, 徳島および広島で小さな山が存在しており, 次の時点では 高原状態となり山がなくなる方向, すなわち高原状態へ向かうと考

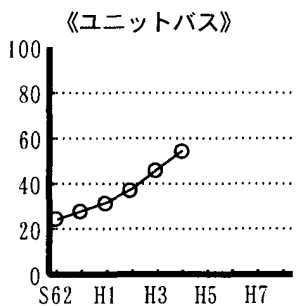

《仏壇置き場》

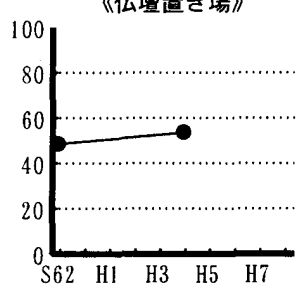

《浴槽の材質》

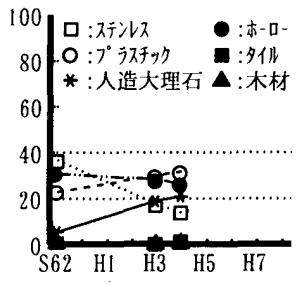

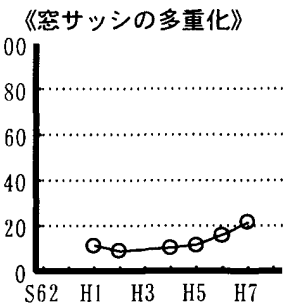

《雨 戸》
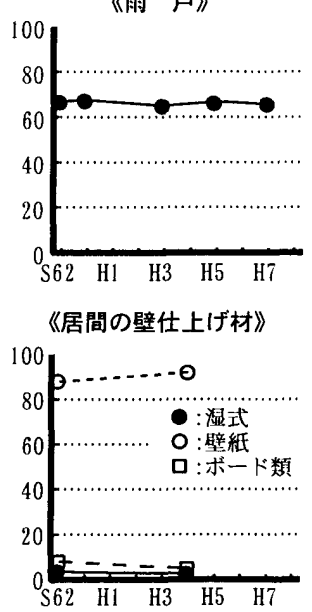

《断熱材の厚さ》

注） X軸は年度（作）を 示し，Y軸は採用率 平均（\%）を示す。

\section{《和室の壁仕上げ材》}

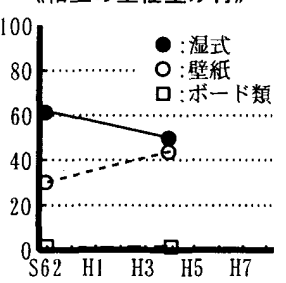

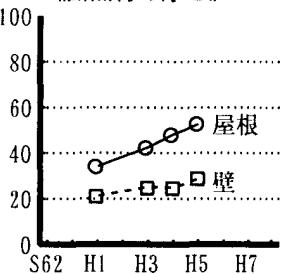

图-2 住宅様式・材料の採用状況の変化 
えられる。台所の流し台は以前はステンレス流し台であったが, 近 年システムキッチンが主流を占めている。これは生活スタイルの近 代化や流行化によるものと考えられ，大都市圈で採用状況が高くそ の地域を採用・普及の起点として圈域が形成され, 都市型の圈域形 成のブロセスを示す。

近代的様式・材料にも関わらず減少しているモルタル・コンクリ 一トをみると（図一 4), 昭和 62 年度では山梨を中心とした東京大 都市圈（東京や埼玉などでも高い採用状況である），島根を中心と した関西大都市圈（大阪や奈良でも高い採用状況である），九州地 方で圈域が形成されている。これも都市型の圈域形成をのブロセス を示しており, 平成元年度ではそれらの地域のみで採用・普及が伸 び山と谷の差が大きくなる。平成 7 年では起点の地域で大きく減少 し山と谷の差も小さくなり，圈域の数も減少する。

伝統的様式・材料は衰退として捉えられ, 総じて大都市圈から衰 退している。続き間をみると（図－5）, 東京, 神奈川, 埼玉, 大 阪, 奈良で平成 8 年度では急激に減少している。その中で年度が経 過しても採用状況が高いのは，山形，長崎といった東北地方および 九州地方であり，高採用状況を維持している。これは現代社会にお いても続き間空間の格式性を強く求めているだけでなく，いまだに 家で冠婚葬祭や寄り合いなどの行事を行っているためである ${ }^{6 ! 。 ま ~}$

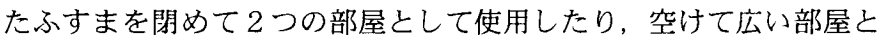
して使用したりという融通性の利く空間構成は, 生活の仕方が多様 化した現代社会においても一定の必要性を残していることを意味し ている。北海道では，続き間が当初から採用していなかった空間・ 様式であったことに加え，部屋を壁ではなくふすまで仕切ることは 暖房効果を低下させること，また大都市圈では続き間を採用する住 宅規模が確保できないこと, さらに洋風住宅に対する憧れが衰退の 一要囚として考えられる。

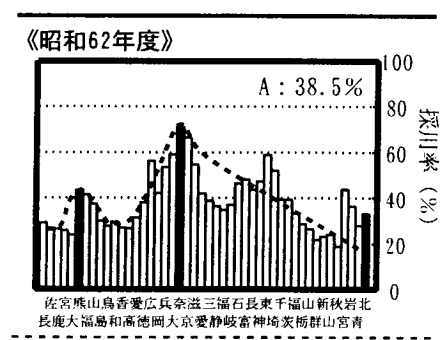

《平成 3 年度》

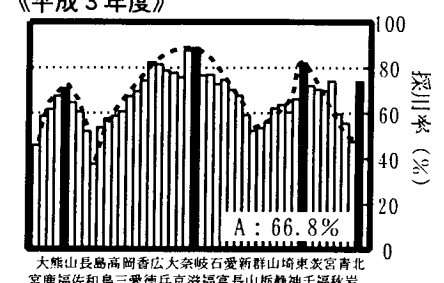

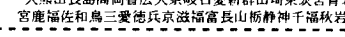

《平成 4 年度》

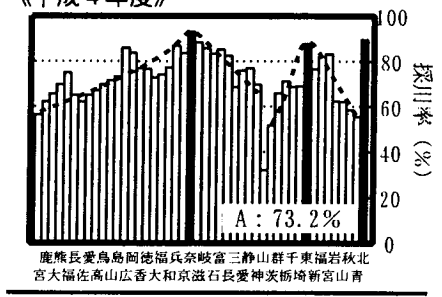

図一 3 システムキッチンの圈域 形成のプロセス

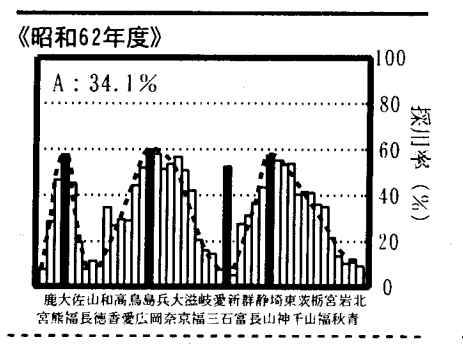

《平成元年度》

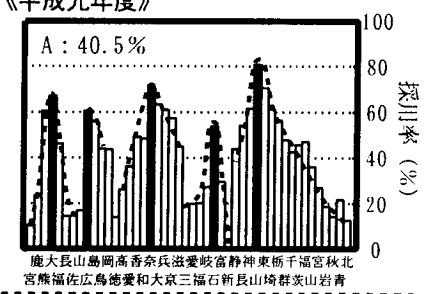

《平成 7 年度》

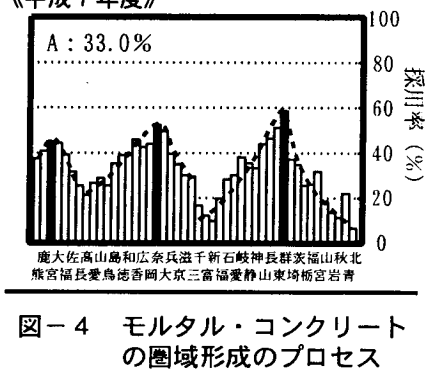

気候対応型とりわけ北方型の圈域形成には 2 つのパターン，「寒 さ」対応における圈域形成と「降積雪」対応における圈域形成が存 在するが, その圈域形成のブロセスは異なっている。「寒さ」対応 の圈域形成を示す住宅様式・材料は, 断熱材の厚さや空サッシの多 重化である。屋根の断熱材の厚さ（図一 6 ）をみる之, 平成 2 年度 では北海道および東北地方で各年度高い採用状況を示し，北海道を 起点として圈域が形成されていたのが，平成 4 年度では長野を起点 とした圈域も形成されており, 新しい山の形成時期と考えられる。 平成 6 年度になると長野および滋賀の近隣地域でも採用を伸ばした 結果, 北海道を起点とした単一の圈域が形成されており，北方地域 の普及の高原状態と考えられる。また，平成 2 年度から平成 6 年度 の間に $30.0 \%$ 以上増加している都道府県は富山, 群馬, 茨城, 岐阜, 和歌山，山口，島根であるが，その地域の採用・普及状況には差が ある。それらの状況の変化をみると, 群馬, 茨城, 富山は平成 2 年 度と平成 4 年度で急激に採用・普及している。それに対し, 岐阜, 和歌山, 山口, 香川, 島根は平成 4 年度から平成 6 年度の間で急激 に採用・普及しており，時期がずれて採用・普及している。これは 採用・普及の起点すなわち北海道および東北地方から遠いためでも あろう。圈域の形成は普及の起点からの距離と，屋根の断熱材の場 合は住宅金融公庫の基準が影響であると考えられる。また，近年の 南方地域における断熱材や空サッシ多重化の採用・普及は「暑さ」 すなわち冷房対応のためと考えられる。

「降積雪」対応の圈域形成ブロセスは金属板および無落雪屋根で ある。金属板の圈域形成のブロセスをみると（図-7），昭和62年 度から一貫して北方地域で高い採用状況であり, 明確な圈域が存在 し，しかも大きな変化はない。このことは北方の一部の地域で高原 状態となっていることを示している。これは「降積雪」対応という 地域限定のため, 先の都市型の圈域形成のブロセスとは異なる。し
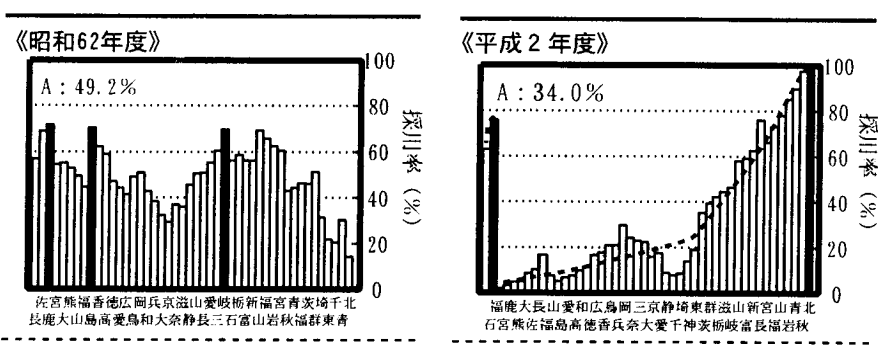

《平成元年度》

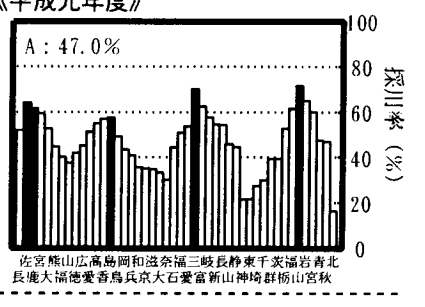

《平成 4 年度》

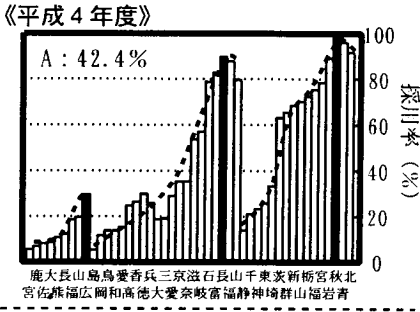

《平成 8 年度》

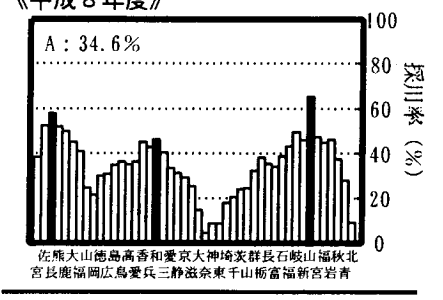

図 -5 続き間の圈域衰退のプロ セス
《平成 6 年度》

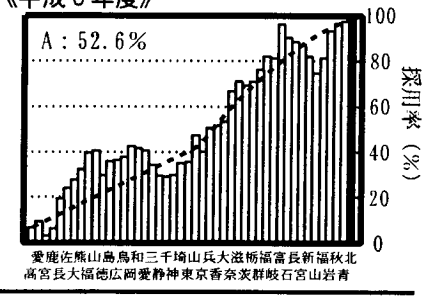
以上）の圈域形成のプロセス
図 -6 屋根の断熱材の厚さ $(80 \mathrm{~mm}$ 
かし北方地域に位置する岩手では $86.9 \% \rightarrow 80.2 \% \rightarrow 77.6 \%$ と减少し ており，これは彩色石綿板の影響であろう。というのは岩手では降 雪が少ないため, 宮城で多用されている彩色石綿板のほうが優位性 が高く，隣接の岩手に普及した結果と考えられる。

雨戸は金属板と同様の普及圈域のブロセスを示し（図一8），昭 和 62 年度から一貫して北海道を中心とした東北地方, 北陸地方, 鳥 取および島根といつた日本海側地域で極端に採用状況が低く，採用 している地域では一貫して高い採用状況である。図ー9に示してい るが, 一貫して採用していない地域は積雪寒冷地域であり, 冬季間 の雨戸の開閒が囷難になるためと考えられる。また採用状況が高い 地域をみると太平洋側が主に該当しており, 台風の影響であると考 えられる。このように台風や降積雪などの気候条件は時間的変化を 受けず，毎年継続して一定地域にくるものであるため圈域形成に変 化しない。これは採用している地域では強い必要性が存在している ためであろう。

\section{5. まとめ}

本研究は各住宅様式・材料が時間的経過によって, どのように採 用・普及（衰退）しているのか, 圈域形成を時間的断面で捉え, 普 及圈域がどのように変化しているのかを分析した。その結果をまと めると，以下のようになる。

(1)住宅様式・材料によって徐々に採用・普及していくものもあれば, 急速に採用・普及していくものもある。このことは地域性との怙 抗の中で普及が進行していることを意味している。本来, 近代的 様式・材料は時間の経過とともに普及していくと考えられるが, 地域や生活に合致しないか，他で優位性を持った住宅様式・材料 が開発・普及されると以前の住宅様式・材料は普及せず，普及し たとしても早晚衰退する。

(2)気候条件によって影響を受けている住宅様式・材料は, 常に一定

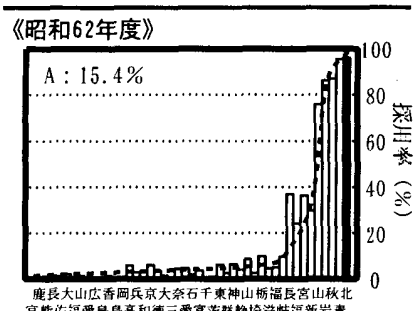

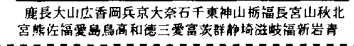
《平成元年度》

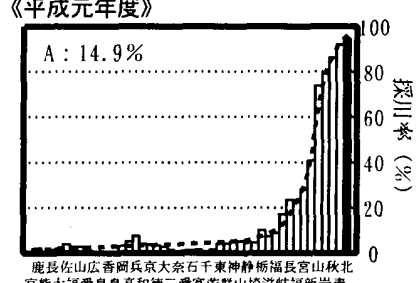

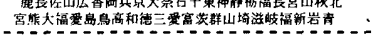
《平成 7 年度》

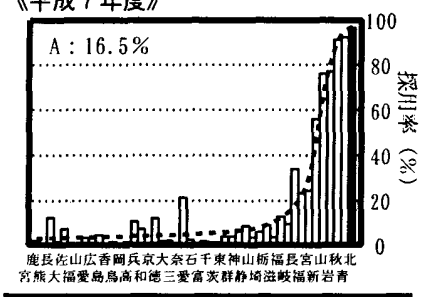

图-7 金属板の圈域形成のプロ セス

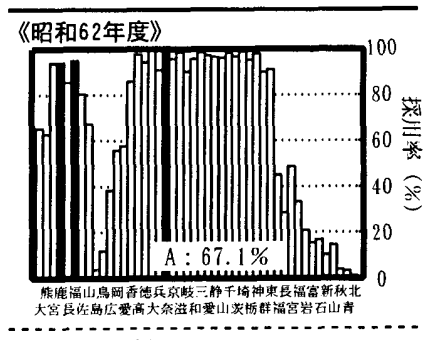

《平成 3 年度》

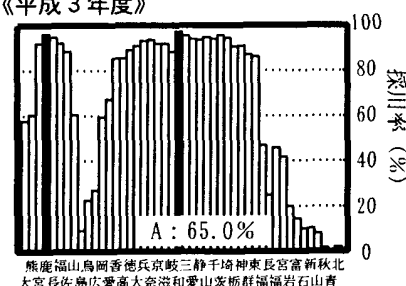

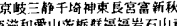

《平成 7 年度》

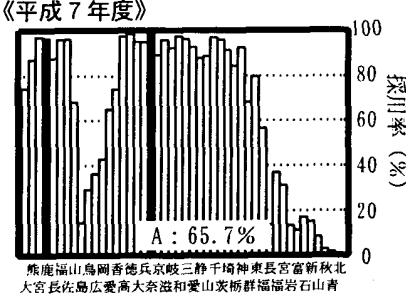

図-8 雨戸の圈域形成のプロセス
の高原状態を維持し圈域は変化しない。このことは気倏条件は採 用・普及に強く影響を与えていることを示す。

(3)一方，伝統的様式・材料は衰退状況にある。その伝統的様式・材 料は, 近代的様式・材料と反対の傾向, すなわち大都市圈および 北方地域から衰退している。また近年の生活スタイルの変化によ って和室のように急速に衰退していく住宅様式・材料もあれば, 精神性の強い住宅様式・材料は徐々に衰退していき, 衰退状況に も差が生じている。

住宅様式・材料は地域条件と関係して普及している。今後の住宅 生産・供給において重要なことは, 生産過程における合理性だけで はなく地域性を尊重した住宅づくりを展開していくことである。

\section{【参考文献および注釈】}

1)鈴木成文：住まいの計画住まいの文化，彰国社，pp. 224～230，1988.11 秋山哲一：住宅生産・供給システムの地域的再編に関する検討（現代八 ウジング論：巽利夫編），学芸出版社，pp.233〜251，1986.3 坊垣和明 : 温暖地における断熱・気密化の効果と課題一住まい方とエネ ルギ消費に関する全国調査から一，日本建策学会北海道支部研究報告集 №.72, pp. $619 \sim 622, \quad 1999.3$ などである。

2)巽は「普及は時間経過・過程と空間送受が重要な要素」と下記の論文で 述べている。

巽和夫ほか：住宅計画・生産・供給における技術・手法の地域圈への普 及過程に関する研究, 昭利 62 年度科学研究費補助金 $\mathrm{A}$ 研究成果報告書, pp. $1 \sim 58,1993.3$

3) 大坦直明, 谷口尚弘 : 新筑戸建住宅における住宅様式・材料の普及構造 に関する研究，日本雪工学会誌 Vol.13 No. 3，pp. 16～23，1997.7

4) 谷口尚弘, 大垣直明 : 新築戸建住宅における様式・材料の普及構造に関 する研究，日本建築学会計画系論文集 第519号，pp. 225～231，1999.5 上記の論文において圈域の設定し分析している。圈域の設定について 簡単に付記しておく。住宅様式・材料の採用率を都道府県ごとに地図に ブロットし，さらにその結果を用いグラフ化している。採用率の地図上 での表現は地理的連続性を極めて上手に表しており，採用率の高い都道 府県から低い都道府県に普及が伝播すると仮定し，各都道府県の採用率 を地図上にブロットし，最高採用率を示す都道府県を普及の極地点いわ ゆる起点（以下，山の頂点）とみなした。その頂点から隣接して採用率 が低下する流㧈（矢印）を描き，隣接する山の頂点からの流れと接する 䂙道府県（以下, 谷) を求め, 山と谷の落差（格差）の関係から圈域を 位置づけている。

5) 昭利 62 年度より住宅金融公庫が公庫融資付新築戸建住宅の都道府県別調 査を実施し，データを公閒している。住宅の間取りや材料などの地域的 な特微を把握するための主要なデー夕を収集している。今まで把握する ことが難しかったデータが含まれている貴重なデータである。

6) 谷口尚弘：戸建住宅における様式・材料の普及構造に関する研究, 北海 道工業大学大学院博士学位論文, 2000.3

\section{【図ー3〜図-8の凡例および注釈】 \\ 凡 例 \\ 洁）横軸は，都道府県（頭文字）。 普及の極地点から地理的に連続 ….. は, 普及の極地点の都道府県 ……は, 圈域の範囲 \\ A は，採用率の平均 $(\%)$ \\ て右側性北地域が位䈯し，左 側が南方地域が位置する。}

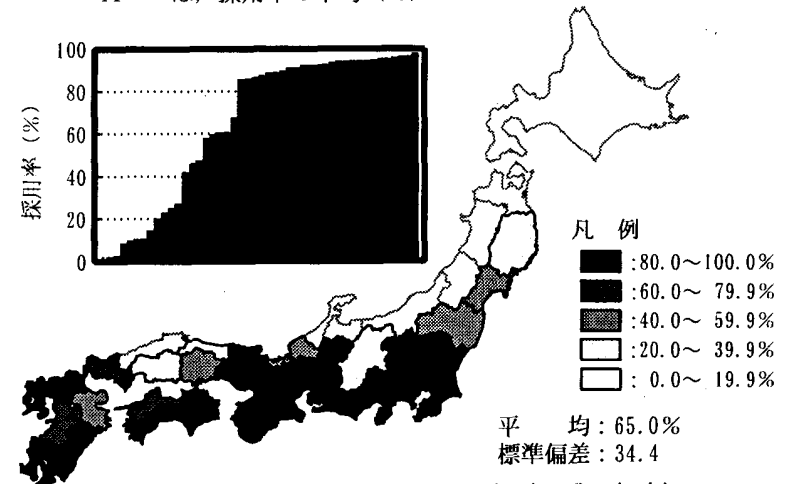

図-9 雨戸の採用状況の分布（平成 3 年度） [2000年 4 月19日原稿受理２000年 7 月26日採用決定］ 